\title{
CORRELATION OF NORTH AMERICAN ENGLISH AND BRITISH ENGLISH DIVERGENCIES IN LEXIS
}

The article focuses on the description of a special type of relationship that arises between lexical units within the corpus of English words in the framework of the sociolinguistic approach. Various ways of correlation between North American and British usages emerge in present-day English due to the action of two processes of the language development favoured by a set of historical, linguistic and sociolinguistic factors: divergence and convergence.

The paper describes the most frequent forms of lexical correlation between North American English usage and British English usage. The research states that the semantic structure of the lexical unit or its register of usage can undergo changes under influences of the other variety. The lexemes, common to both national varieties with partial coincidence of the semantic structure and, sometimes, with shifts in the register of usage, are more affected by the process of convergence. The part of the English lexis less affected by convergent processes comprises common lexemes with the split in the semantic structure, the components of which are different or antonymic. The part of the present-day English lexis likely to be involved in the process of internal borrowing mostly includes lexemes specific to US English or British English with, or without lexical equivalents in the other variety.

A special kind of correlation between lexical units of common origin can bring about usages functionally confined only to one variety. The functional predominance can contribute to the formation of different chains of

synonyms actualized in each of the varieties. When lexemes have lexical equivalents specific to one of the national varieties of English, the so-called "pseudo-synonymous relations" within the English lexical system can arise.

Key words: North American English usage, British English usage, common lexis, lexical equivalents, synonyms.

Introduction. In the sociolinguistic contexts of English that have been developing of late, new ways in which English lexemes in usage in different national varieties of English are connected, interact and affect each other may become the focus of attention in language studies. A permanent evolution of English as a language system realized in many kinds of varieties of English makes scholars face new challenges of an adequate description of the corpus of English or ways of word use in present-day English communication. The formation of numerous varieties of English outside the land of its origin followed various types of colonization, natural or economic migrations of English-speaking communities overseas, hand in hand with separate cultural development and changes in the mode of the sociolinguistic behaviour of English-speaking people. The direct and natural consequence of the isolated development of the English-speaking communities is the appearance of different variations in language usage that have sprung up due to the action of the splitting off movement from the mainland variety. The most important language-external factors that influence the choice between the varieties are sociolinguistic variability, the influence of social change and mobility on the development of language, and the differentiation and amalgamation of varieties, including contact phenomena [1:9-10]. Due to the greater intensity of global communication, the contact phenomena can promote the process of convergence between the varieties of English. Three factors are behind divergent and convergent processes of development: historical, linguistic and sociolinguistic. The process of divergence shows the tendency to differentiation in the development of lexis, both in the corpus of lexemes and in their use, sometimes with shifts in the register of usage, or modifications within the semantic structure of lexical units. The process of convergence, especially characteristic of the evolution of relations between North American English usage and British English usage today, can result in convergent levelling of divergences, in bringing in new lexemes or new ways of usage owing to a complex interaction of the communities. The process of convergence due to sociolinguistic and linguistic factors, in the form of US English influences on British English, started already in the previous century, but was restricted to occasional usages. This process has been accelerating due to the changes in the present-day sociolinguistic contexts of English, the most noticeable of which are changes in the scope and character of social functions of US English, its rise as a British English rival in worldwide communication, and an increasing force of US English influences on British English [2]. A greater scale of global public and specific communication of today also causes convergent processes promoted by an increasing impact of British English on US English usages, especially in oral, informal discourse. The working of convergence can cause levelling or removal of regional language divergences and penetration of lexemes specific to the varieties into the common lexis of English. 
The vocabulary of the English-speaking world treated as a fundamental unity with only marginal national variation presents itself a complicated, intertwined phenomenon [3: 29]. The coexistence of lexical units of different communicative or functional value used in different English varieties within the same lexical system can lead to the rise of definite points of difficulty in language use.

The aim of the suggested study is to look into the nature of the relationship between lexemes of the most-spread national varieties of English in the lexical corpus of the same language system and to comment on most frequently found ways of lexical interaction between US English and British English usages. The paper highlights the complexity of lexical correlative relations that are the result of the action of two processes of the language development determined by a set of historical, linguistic and sociolinguistic factors: divergence and convergence.

Discussion. The full corpus of present-day English includes the common lexis used in communication in all national and area varieties, with full or partial coincidence of the communicative potential, and peripheral individual lexemes specific to each of the varieties. Divergent and convergent processes in the language development create an increasing complexity of relations that arise between lexical units of different varieties within the frame of the same language system and in language usages in actual communication. Divergence and convergence usually affect usages in oral informal discourse and later, with the time to pass, visible transformations in the semantic structure of the lexeme can take place.

Being functional forms of the English language, US English and British English share, sometimes with different modes of actual realization in communication, the major part of the English lexis. The dominant part of the English corpus includes lexemes that are common to both national varieties with full coincidence of the semantic structure, with an equal communicative potential and with no difference of use in many types of discourse. The process of divergence reveals itself in the appearance of new lexemes that in many cases are lexical equivalents to the existing lexemes in the other variety and in the existence of common lexemes that display deviations in language use conditioned by the historical, sociolinguistic and cultural background of evolution specific to either of the varieties. The most visible of them are differences in the register of usage, as any variety of English keeps its individual character of usage, the modification of the semantic structure of the lexical unit with the development of components that are characteristic of only one national variety and the difference in the semantic structure, sometimes with an antonymic semantic split. In lexemes with a complicated semantic structure, the language divergences may become visible in three principal ways. These can be the preservation of old meanings lost or peripheral in usage in other variety, the inclusion of new meanings into the semantic structure of the lexeme and the shift in the register of usage. Some British English dialectal words can become literary standard in US English usage or lexemes can refer to different types of register, informal or specific, in the other variety.

The most frequent language distinctions between lexemes of common origin develop due to the introduction of new components into the semantic structure of the lexical unit, the conservation or modification of old meanings preserved in usage only in one variety of English and the shift in the register of usage. In present-day English usage, the common lexeme governor (ME) means the person in charge of governing a country that is under the political control of another country. In US usage, the lexeme additionally means the person in charge of governing a state in the USA (the governor of Arizona). In British English, the lexeme can mean a member of a committee that controls an organization or institution (a school governor), or the person in charge of an institution (the governor of the Bank of England) [4; 5]. The lexeme stroller (1608), of common origin, has the meaning one who walks in both varieties, but in North American usage, it has acquired additional meanings: a tramp, vagrant, an itinerant actor and a pushchair [6]. To wash up means (of water) to carry something onto land in both varieties and to wash dishes, plates and knives after a meal in British English, to wash hands in US usage [5]. The lexeme homicide (ME), of common origin, has remained as a law term in Britain, whereas in North American common usage, it can mean killing, murder; the police department that deals with murders [4; 6; 7].

The process of divergence can cause such deviations in the semantic structure of the lexeme of common origin that its modifications can actualize only in one variety of English. When the semantic components of the lexical unit do not correspond and differ completely or partially in US and British usage, the functional split in the semantic structure of the lexeme takes place. In some cases, the basic meanings are antonymic. The lexical unit city desk of common lexis can mean a newspaper department that deals with local news in US usage and a newspaper department that deals with financial and business news in British English [4; 5; 6]. The lexeme ratepayer (1845) in the UK means a person liable to pay taxes, whereas in the USA, it means a customer of public utility [6; 7]. The lexeme geezer (1884) which originated from a dialect pronunciation of the word guiser meaning one who mutters stands for a queer, eccentric person, said humorously about elderly men in the USA, whereas in British informal discourse, it means a man $[6 ; 7 ; 8]$. Call box (1877) is a telephone for emergency use in the USA, whereas in Britain, it is a public telephone booth [6;7]. The lexeme to table of common origin denotes antonymic notions in the USA and Britain and means to postpone consideration of something (such as a bill) to some time in the future in the USA, to put on the agenda and present formally for consideration in Britain $[4 ; 5 ; 6 ; 7 ; 8]$.

Any variety of English enjoys its individual portion of English lexis. It includes, as marginal national variation, lexemes that are in use only in one variety of English, not found outside. They can be innovations or old, outdated, lexemes, or dialectal words that shifted to literary standard, as, for example, the old lexeme cloture (1871) 
preserved in US English. The separate evolution of both varieties has resulted in the development of a part of the lexis composed of new lexemes characteristic of each of the varieties in oral informal or technical specialized discourse. These lexemes are limited in usage by a specific character of sociolinguistic or cultural contexts of English in the USA or Britain. In this case, divergent processes can result in the appearance of lexical equivalents restricted to usage inside the variety of English. The following lexemes are characteristic of British use: to chunter (1599), doddery (1866), brolly (1873), ratbag (1890), to hoover (1920s), clanger (1948), chuffed (1957), cagoule, kagoul (1950s), contraflow, to bucket down, E-number, bun fight, fightback. The North American lexemes are critter (1815), cross-street (1827), drugstore (1845), grubstake (1863), crackerjack (1893), gabfest (1897), hooey (1912), doohickey (1914), doozy, doozie (1916), bull session (1919), dumpster (1937), downhome (1938), cookout (1947), cookie cutter (1963) [4; 5; 6; 7]. Loans, especially of later time, can also differ due to separate ways of culture development and due to various social, political and multicultural contacts of English-speaking communities with different ethnic communities: North American cum laude (from Latin), British couchette (from French). Some lexemes of common origin may vary in pragmatic value as, for example, the adverb really can show different emotions in US and British usages. In North American usage, really can additionally show that a person agrees with the interlocutor, whereas in Britain, really can additionally show that a person is angry or disapproves of something: Glen can be such a jerk. - Yeah, really! (American English); Really, Larry, you might have told me! (British English) [4].

The process of convergence that often affects common lexemes with partial coincidence of components of the semantic structure can lead to the levelling within the common corpus of the lexis. In this case, convergent processes can reveal themselves through the removal of the regional restrictions of usage due to the natural ways of language development or due to the mutual influences of varieties upon each other. Convergence is not a one-way process; both varieties can influence each other and exert its influential potency over other varieties of English. Convergence due to reciprocal influences can be visible through the introduction of new ways of usage or new elements into the semantic structure of the lexeme, or through the infiltration of lexemes originally found in or specific to the usage in one of the varieties. In British usage, it can be seen in reintroduction of old lexemes and outdated meanings $(\mathrm{mad})$, in the shift of the register when a dialectal lexeme is included into the neutral part of the lexis $(\mathrm{kid})$ and in the modification of the semantic structure of the lexeme with an introduction of new semantic components, sometimes with the rearrangement of meanings. US influences can have a strengthening effect that can result in the increase of the communicative potential of the lexeme as, for instance, the lexeme guy that has become popular in informal British use in the meaning a man, a bloke [9]. British influences mostly become evident through the introduction of British ways of usage. Generally, convergent processes can trigger two forms of interaction between lexemes of specifically US English or British English usage. These lexemes can appear as internal borrowings in other varieties or the use of lexemes specific to one of the varieties may be affected by influential processes that can lead to the removal of distinctions between the varieties of English. Lexical equivalents can join the common corpus of English enriching the common lexis and can drift to the status of full synonyms, sometimes with the preference of usage in one of the varieties, thus extending chains of synonyms of words. The intermediate stage of the penetration of new lexemes or new ways of usage is usually marked as especially British or US in today's dictionaries. Chiefly or especially North American lexemes are lumber in the meaning wood that is prepared for use in building, husky in the meaning big and strong (about a man or a boy), movie, cookies. Chiefly or especially British English lexemes are timber in the meaning wood that is prepared for use in building, to demob, prawn $[4 ; 5 ; 6 ; 7]$.

The North American lexeme doomster (ME) keeps the meaning a judge, archaic in British English, whereas in British informal use, the lexeme doomster means a person who predicts that very bad things will happen. In the USA, doomsayer (1953) is a lexical equivalent to the British use of doomster. Due to North American influences, the lexeme doomsayer, marked especially North American, is penetrating into the present-day British usage and its use is becoming synonymous with the British use of the lexeme doomster $[4 ; 6 ; 7 ; 8]$. The common lexeme thermos (1907) that has popularity of bottom $30 \%$ of words in US usage has accepted the British vacuum flask (1917) as a synonym with popularity of bottom $10 \%$ of words. The British lexeme to clock out marked as chiefly British gains popularity of bottom $10 \%$ of words in US usage as compared with its US lexical equivalent to punch out (1893) which gives popularity of bottom $30 \%$ of words in US usage. The British TV term chat show (1969), marked as chiefly British in the Merriam Dictionary, gains popularity of bottom $20 \%$ of words in US usage as compared with the US TV term talk show with popularity of bottom $30 \%$ of words in US usage. A good illustration from this online dictionary is one of the latest examples of usage: "Not all of Comey's planned appearances - which include stops in TV chat shows on CBS, Fox News, CNN, ABC and MSNBC - are set up as live, taped town halls. "Miami Herald" 31. Mar. 2018 [6]. The lexeme friendly (noun), of common origin (1870), marked as chiefly British in the meaning a game played for practice or pleasure, not a part of a serious completion, becomes possible in the USA and re-enters North American usage with a new meaning. The Merriam Dictionary gives the following illustration from New York Times (17 June 2018): Sunday's defeat may even prove a useful jolt out of any complacency, though,..., poor performances in friendlies against Saudi Arabia and Austria before the tournament were supposed to be warnings [6]. 
The present-day British lexeme clanger, neither registered in the Shorter Oxford Dictionary (1972) nor in the Webster Dictionary (1968), can already be found in The North American Press: So teams won't have him around to leave open for rim clangers (Cleveland.com. 8. Feb. 2018) [6; 8; 10]. The lexeme cakewalk (a surprisingly easy task) recently marked as North American by such British dictionaries as Longman Dictionary of Contemporary English (2012) has entered British English and has become common to both varieties [4; 6; 7]. The lexeme bucket shop demonstrates a complicated crossover pattern of reciprocal influences experienced by it due to convergent processes. The lexeme bucket-shop appeared in the USA where it originally meant a saloon for selling liquor (1870), later it developed the meaning an unauthorized office for smaller gambling transactions (1882) [8; 10]. The word acquired a derogatory attitude in informal discourse and penetrated into British usage with the meaning an unauthorized office for speculating in currency or stocks. Later the lexeme additionally began to denote a travel agency that sells cheap plane tickets in British informal usage [4; 5]. These days the lexeme bucket shop stands for any company that specializes in selling cut-price goods, especially airline tickets in US usage and has joined the corpus of common lexis of English [6].

The infiltration of lexical units, specific to each of the varieties of English into the full corpus English can lead to the formation of pseudo-synonymous sets of lexemes, the members of which are semantic and functional equivalents confined to communicative and functional restrictions by one of the varieties. Pseudo-synonyms are lexemes that are lexical equivalents of the same register of use characterized by complementary distribution imposed by sociolinguistic and territorial restrictions. The US English teeter (1846); teeter-totter (1905) is a lexical equivalent to the British English seesaw (1640). The US English flashlight (1886) is a lexical equivalent to the British English torch (ME). The US English wrench (1794) is a lexical equivalent to the British English spanner (1700). The US English zucchini (1925) is a lexical equivalent to the British English courgette (1873). The US English diaper (ME) is a lexical equivalent to the British English nappy (1927). The US English eggplant (1767) is a lexical equivalent to the British English aubergine (1794). The North American English ladybug (1699) is a lexical equivalent to the British English ladybird (1592). The North American English station wagon (1929) is a lexical equivalent to the British English estate car (1948). The North American English money order (1802) is a lexical equivalent to the British English postal order (1864) [4; 5; 6]. A more complicated pattern arises when only one semantic component of common lexemes forms pseudo-synonymous relations. For instance, the lexemes vacation (the USA) and holiday (Britain) are semantic and functional equivalents in the meaning an extended period of recreation, usually spent away from home [4; 6; 7]. The US English antenna (1900) can be a lexical equivalent to the British English aerial (1902) in the meaning a wireless aerial. The US English rutabaga (1789) is a lexical equivalent to one of the meanings of the British English lexeme swede (1812). The common lexeme stroller in one of its meanings can be an equivalent to British lexemes buggy and pushchair in the USA whereas in others it keeps meanings that are specific to North American usage [4].

Both processes, divergent and convergent, can affect the formation of semantic groups within the corpus of common lexis of English. Divergent processes can encourage the formation of new chains of synonyms that can differ in each of the varieties due to the existence of different semantic components in the semantic structure of the lexeme or due to the inclusion of lexemes specific to that variety. The process of divergence can influence the composition of the semantic groups so that their components, sometimes, do not coincide in both varieties and can consist of different constituents. In British usage, the adjective ratty enters into a set of synonyms with the head meaning irritable, irritated, whereas in North American usage, ratty forms a chain of synonyms with the meaning shabby $[11 ; 12 ; 13]$. The lexeme to quit of common origin can enter different number of chains of synonyms due to the divergent processes that have affected its usage in Britain and the USA. In today's British use, the lexeme to quit joins two groups of synonyms: a) to leave, to depart from, to withdraw from, to abandon, to desert; b) (informal) to resign from, to give up, to relinquish, to vacate, to walk out on [11]. In North American usage, it can be a part of three chains of synonyms: a) to stop doing, to cease, to desist, to yield, to surrender; b) to leave, to go away, to withdraw, to skip or flee the coop from; c) to resign, to leave a job, to renounce, to reject, to relinquish [12].

The hierarchy of elements in sets of synonyms can vary depending on the dominant meaning of the lexeme in US or British use. The development of the semantic structure of the lexeme mad can well illustrate the process of levelling under the impact of bilateral usages. The lexeme mad, of common origin, has kept the meaning angry characteristic of its usage in Early Modern English in present-day North American usage. In today's British usage, this meaning is becoming possible in informal discourse, though marked as especially North American. Still, the British Dictionaries do not list synonyms to that meaning and register synonyms to the lexeme mad under the leading meaning insane or three additional meanings foolish, enthusiastic and frantic, hysterical [11]. In dictionaries printed in the USA, the list of synonyms to the lexeme mad usually starts with the meaning angry, the other sets of synonyms are connected with the meanings insane and enthusiastic [12].

The inclusion of lexemes from both varieties into the common lexis of English or modifications in the semantic structure of lexemes under interactive influences can give rise to synonyms with disproportionate actualization. Lexemes from US English and British English can enter groups of synonyms the members of which are synonymous only in one variety of English. The verb to broil is synonymous with the lexeme to grill (1668) in the 
USA, but is perceived as a North American equivalent to the lexeme to grill in Britain [5; 6; 7]. The lexemes fall / autumn can be synonyms in US usage, whereas in British English they are not synonyms. Convergent processes have almost removed functional divergences in British English between the lexical units: can / tin in the meaning an airtight container in which food or drink is stored over a long period; cabin / cottage, I guess / I think; and in North American English between: chalkboard / blackboard, trash / rubbish [6; 7]. The lexemes trash and rubbish are synonyms in the USA, but in Britain, they can be lexical equivalents: trash in the meaning litter, refuse is North American usage [6; 7]. In British English, the lexemes childminder and babysitter are synonyms, whereas for North American usage, babysitter is a lexical equivalent for British English childminder [6; 7]. In North American English, the lexemes chalkboard and blackboard are synonyms, whereas for British English usage, blackboard is a lexical equivalent for North American English chalkboard.

The lexemes pavement and sidewalk are lexical equivalents in the meaning a flat part at the side of a road for walkers, at that, pavement is a usual word for British people and is a part of the semantic group in the notional category PATH that includes walkway, footpath, footway [11]. Its equivalent in North American usage is the lexeme sidewalk that enters the set of close synonyms in the notional category PASSAGE including such lexemes as, walk, footwalk, crosswalk, footpath, footway [13]. The lexemes pavement and sidewalk are common by origin to both varieties. The lexeme sidewalk (1667) became rare in British usage but remained in North American use in the meaning a raised part for foot-passengers along the side of a street, road (1739) [8]. The lexeme pavement (ME) in the meaning a paved surface, an undivided surface of cement, asphalt, concrete with the development of the additional sense of a roadway has become dominant in the North American use. In British English, the Middle English meaning transformed into the paved part of a public thoroughfare and later narrowed into the paved footway by the side of a street as distinct from the roadway. [8]. In the USA, the lexeme pavement can most frequently form synonymous relations in the notional category COVERING with the following lexemes: blacktop, asphalt, flagstone [14].

In some cases, the same lexeme of common origin can form chains of synonyms that include different lexemes due to a specific modification of the semantic structure or due to the individual separate development of the oral discourse in US or British usage. In British English the lexeme fellow (OE), becoming old-fashioned or informal in the meaning a man or a boy, forms a chain of synonyms with the lexemes: boy, person, guy, geezer, lad, fella, chap and bloke. In North American English, fellow in this meaning can be synonymous in informal discourse with the lexemes: boy, man, chap, dude, hombre, and guy. In North American usage of the lexeme fellow, the lexemes that are connected with the meaning an associate: companion, friend, comrade, cohort, chum, co-worker, colleague, compatriot, pal are more typical synonyms $[12 ; 13 ; 14]$.

The levelling processes in usage of common lexemes with a semantic split seems less possible due to a sharp difference between the semantic components that developed in different sociolinguistic contexts. The lexemes with a semantic split can form different sets of synonyms reflecting a specific character of their semantic structure. The lexeme homely (ME) in British English usage enters the set of synonyms which includes, adjectives: comfortable, homelike, cosy, easygoing, welcoming, friendly, whereas in US English usage, the lexeme is a part of the group: unattractive, ordinary, drab, plain-looking, plain, not good-looking, uncomely [11;12;13;14].

Due to the process of convergence, chains of synonyms can be extended through the removal of divergences and inclusion of lexemes formerly marked as British English or US English into common English usage. For instance, in British use, the set of synonyms with the head lexeme child nowadays also includes kid, formerly marked as North American. In North American usage, the set of synonyms consisting of backpack, knapsack, packsack also includes the lexeme rucksack marked as especially British in British dictionaries some years ago [4; $5 ; 6 ; 7]$.

Under convergent influences, lexical equivalents can become synonymous with small difference in usage, usually distinguished by a dominant frequency of usage in North American or British English discourse. In presentday English, the lexemes luggage and baggage are becoming synonyms in the meaning bags and suitcases with personal belongings carried by a traveller in both varieties $[6 ; 7 ; 11 ; 12 ; 13]$. Luggage has become a usual word with popularity of bottom $40 \%$ in US English use. Here is an example from the North American press: Commercial air offers three ways to transport pets: as carry-on, cargo or checked luggage (chicagotribune. com. 30 April 2018) [6].

Conclusions and research prospects. The evolution of the English language in the USA and Great Britain has been going on along the same lines but in different sociolinguistic contexts. Each variety keeps its individual character determined by its sociolinguistic and cultural background. The process of language development that characterizes each of the varieties of English, due to convergent and divergent tendencies, may result in levelling of the existing language differences, or in making the two varieties drift apart. The convergent process can most frequently actualize in the introduction of new ways of usage and in the modification of the semantic structure of the lexeme by including new semantic elements. The acceptance of the formerly peripheral forms into wide usage changes the stock of the common vocabulary. The inclusion of lexemes specific to each of the varieties into the common corpus of English lexis brings its expansion and increases its communicative potential due to the processes of divergence and convergence. A further investigation into the frequency of usage of lexemes introduced or 
modified in their semantic structure under the reciprocal influences experienced by British and North American can prove fruitful in studying the relationships between these two most spread varieties of English.

\section{REFERENCES}

1. Rissanen M. On Writing a History of English : Variation and Change / Matti Rissanen // The European English Messenger - S. L. Logroño : Gráficas Pevisa, Volume VIII, Issue 1, Spring 1999. - 9-11 p.

2. Yevchenko V. V. American English in Its Historical and Sociolinguistic Contexts / Vira Volodymirivna Yevchenko // Zhytomyr Ivan Franko State University Journal : Philological Sciences - Zhytomyr : 2017, Vol 2 (86). - 23-28 p.

3. The Cambridge History of the English Language : in 5 volumes / Vol. IV. 1776 - 1997 [edited by Suzanne Romaine. General Editor Richard M. Hogg]. - Cambridge : Cambridge University Press, 2007. - 761 p.

4. Longman Dictionary of Contemporary English. New Edition for Advanced Learners [Ed. Director M. Mayor]. Harlow : Pearson Education Limited, 2012. - 2081 p.

5. Oxford Advanced Learner's Dictionary of Current English. A. S. Hornby. Seventh edition; [Chief Editor Sally Wehmeier]. - Oxford University Press, 2005. - 1923 p.

6. Merriam-Webster Dictionary [Electronic resource]. - Access mode : https://www.merriam-webster.com/dictionary.

7. English Oxford Living Dictionaries [Electronic resource]. - Access mode : https :// en.oxforddictionaries.com.

8. The Shorter Oxford Dictionary on Historical Principles : [in two volumes] / Third Edition. [Revised and edited by C. T. Onions]. - Oxford : At the Clarendon Press, 1972. - Vol. 1 - 1306 p., Vol. 2 - 2515 p.

9. Yevchenko V. V. North American English and British English: Two Aspects of Development / Vira Volodymirivna Yevchenko // Zhytomyr Ivan Franko State University Journal : Philological Sciences. Zhytomyr : 2018, Vol. 1 (87). -31-36 p.

10. Webster's New Twentieth Century Dictionary of the English Language. Unabridged. Second Edition based upon the broad foundations laid down by Noah Webster. - Cleveland and New York : The World Publishing Company, 1968. 2129 p. + Supplement. -160 p.

11. Oxford Paperback Thesaurus. Third Edition. [Ed. by Maurice Waite with Lucy Hollingworth and Duncan Marshall]. Oxford University Press, 2006. - 930 p.

12. Random House Roget's Thesaurus. Fourth Edition. [Editor Joyce O'Connor]. - N.Y. : Ballantine Books, 2001. $709 \mathrm{p}$.

13. The New American Roget's College Thesaurus in Dictionary Form. Third Revised Edition Prepared by Philip D. Morehead. N. Y. : A Signet Book, 2001. - 902 p.

14. Roget's $21^{\text {st }}$ Century Thesaurus in Dictionary Form. Third Edition. [Ed. by The Princeton Language Institute : Barbara Ann Kipfer, Ph. D., Head Lexicographer] - N.Y. : Bantam Dell, 2006. - 962 p.

\section{Евченко В. В. Корреляция отличий североамериканского и британского вариантов английского языка в} лексике.

В статье исследуются основные параметры соотношения лексических особенностей североамериканского и британского вариантов английского языка в лексике, с точки зрения взаимодействия процессов дивергенции и конвергенции с учетом исторического и социолингвистического факторов языковой эволюции. Анализируются основные изменения форм корреляции североамериканского

и британского использования лексических единиц английского языка, и описывается влияние этих изменений на формирование и состав синонимических групп. Устанавливаются группь лексем наименее и наиболее устойчивых процессу конвергенциии.

Ключевые слова: североамериканское использование, британское использование, общая лексика, лексические эквиваленты, синонимы.

\section{Свченко В. В. Кореляція відмінностей північноамериканського та британського варіантів англійської мови в лексиці.}

У статті розглянуто основні параметри співвідношення лексичних особливостей північноамериканського та британського варіантів англійської мови в лексиці, з точки зору взаємодії процесів дивергениї та конвергениії з урахуванням історичного и соиіолінгвістичного факторів еволюиії мови. Проаналізовано основні зміни форм кореляиї північноамериканського та британського вживання лексичних одиниць англійської мови та описано вплив циих змін на формування і склад синонімічних груп. Встановлено групи лексем найменш та найбільш стійких до процесу конвергениії.

Ключові слова: північноамериканське вживання, британське вживання, спільна лексика, лексичні еквіваленти, синоніми. 